\title{
FASTING THERAPY AS SELF-CONTROL
}

Sholehati Rofi'ah Jamil

Universitas Islam Negeri Raden Fatah, Palembang, Sumatera Selatan

Email : sholehatirofiahjamil@gmail.com

\begin{abstract}
Fasting is familiar for Muslims around the world. One of the compulsory worship for Muslims is fasting during Ramadhan. Fasting is refraining from something that breaks fasting with a specific intention-fasting from dawn to sunset. Fasting not only suppresses appetite for food and drink but also restrains desire during the day. Fasting can also be said to be self-controlling from things that are detrimental or negative. We know that the current era of globalization has dramatically changed the pattern of people's lives. Good in terms of dress, talk, and food. Therefore this paper discusses fasting therapy as self-control. Various studies explained that fasting and getting the reward of fasting could also control emotions, avoid various diseases, and elevate human beings for the better. A person who does fasting will sincerely get a reward, the remission of sins, both sins in the past and sins that will come.
\end{abstract}

\section{Keyword: Fasting, self-control}




\section{INTRODUCTION}

Nowadays, the modern lifestyle currently adhered to by humans tends to make humans like instant things. As a result, they tend to be sedentary and like eating instant foods with high sodium content. Implementing a healthy diet cannot guarantee that we will always be healthy, but paying attention to dairy food consumption can minimize the risk of someone's possibility of developing a disease(Kadir, 2019).

A Muslim is accustomed to fasting even outside the month of Ramadan. (Royanulloh \& Komari, 2019). Fasting is the willful refrainment from eating and drinking from dawn to sunset, with the intention and conditions. An Al-Quran reveals that fasting is an activity for believers to reach the level of "taqwa." The al- Baqarah: 183 explains fasting as follows:

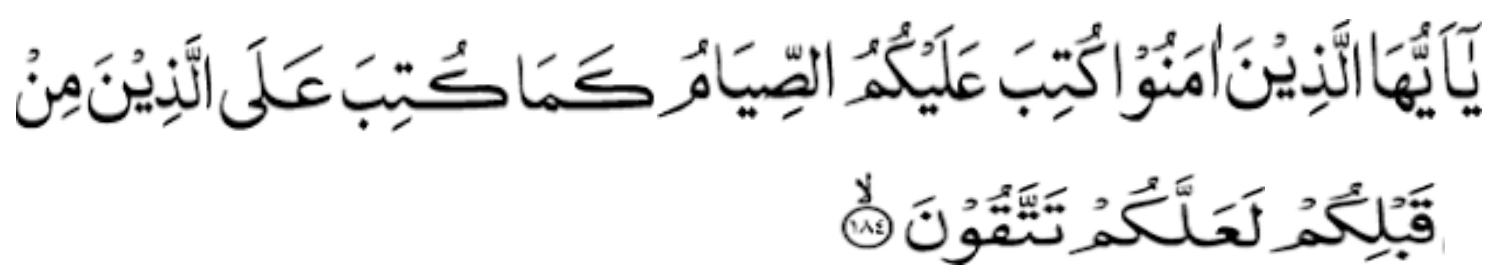

" 0 you who have believed, decreed upon you is fasting as it was decreed upon those before you that you may become righteous."

(Gusmian, 2015)said that fasting has three aspects. One of them is the moral aspect (akhlaqiyyah) which is the base of moral specialists. The moral aspect is easy to understand because of the fasting are education and habituation discipline, obedience, acceptance of inner and outer rules that established, obedience to the leader, cases a barrage, durability, and resistance to the power of lust, strengthening encouragement to good deeds. This dimension is what makes fasting has social value. (Setiawan, 2017)

Moreover, fasting has benefits for health. The health dimension discusses a form of miracles of the Quran, which revealed along with modern science development. Modern knowledge proves that fasting is not harmful to the body as long as it follows the Shari'a corridors. Fasting can improve a person's physical, medical, and biological qualities (Setiawan, 2017). This article aims to explain fasting therapy as self-control that has benefits to the moral and health dimensions. This article also explains that fasting can draw closer to Allah and practice control of desire. 
The author uses the literature study method carried out by collecting data related to the problems discussed in this paper. The data support reference literature obtained from several literature sources like a textbook, research, and scientific journal.

\section{DISCUSSION}

The emergence of various kinds of diseases that afflict many humans, especially in modern times, is caused by anxiety, mental disorder, severe stress, and impaired and improper diet. Moreover, eating and drinking excessively. Restlessness, anxiety, mental tension, severe stress will cause nerves to become tense and increase confusion, affecting the nerves of the stomach, often causing digestive difficulties, gastric ulcers (ulcers), abnormal heart rate, difficulty sleeping, and dizziness. Especially now that everyone has unstable emotions, sometimes even trivial things can cause emotions that lead to extreme anger.

We cannot control the various emotional states that arise from our bodies. We can only control our behavior. It makes us constantly have to exercise in order to control the anger. One way to control it is by fasting. The essence of fasting is self-control and when a person can control himself against the impulses that come from outside and from within him is a mentally healthy person.

(Nuraisyah, 2019) state that sunnah fasting is excellent and can change life's nature. Fasting forms good morals such as being humble, not arrogant, helping each other, respecting each other, more controlled emotions, calmer mind, healthier body, and high generosity.

Fasting (shaum) means abstaining. In Islam, fasting means refraining from eating, drinking, and sexual activity from dawn to sunset. It is accompanied by spiritual fasting, refining from all kinds of desire, negative thoughts, and evil deeds and words (Julianto \& Muhopila, 2015). Puasa dalam Islam merupakan bentuk latihan spiritual untuk mendekatkan diri kepada Allah. Fasting in Islam is a form of spiritual practice to get closer to Allah. Fasting is a ritual of worship that requires humans to control themselves, including anger.

In this modern era, it is tough for humans to rely on their desires (lust) . It is not easy to control a desire. Humans are not satisfied with their existing lives and have excessive consumption. As we know, humans like to buy food excessively. This kind of attribute is an exaggeration, in the word of Allah Almighty. QS. al-A'raf / 7: 31. as follows: 


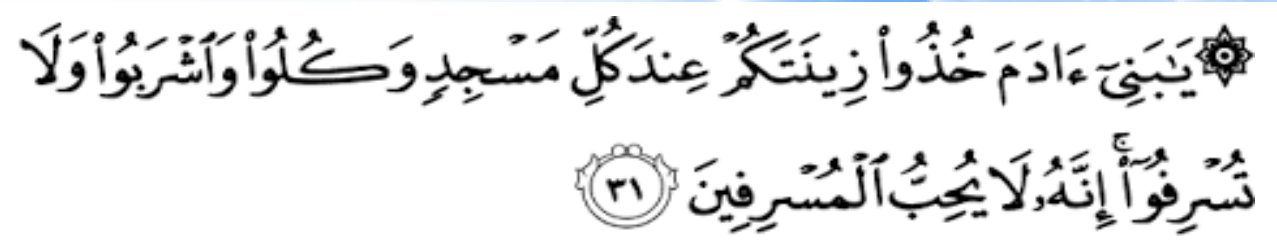

O Children of Adam! Look to your elegance (by dressing correctly) at every time and place of worship, eat and drink but exceed not the bounds, for He does not love those who exceed the bounds."

Rasulullah said that excess makes faith weak because it shows the heart's emptiness, releases its majesty and is filled with lust. Overeating will interfere with the digestive process. Besides, overeating can cause nausea and vomiting. Therefore we must be able to control ourselves by fasting.

Wahjoetomo and Najib's research results concluded that fasting was beneficial for improving physical or physical health. Fasting helps improve physical health. Fasting reduces the amount of food that enters the body so that the work of several body organs such as the liver, kidneys, and stomach can rest. Fasting allows digestion to rest for several hours to normalize and guarantee its functional effectiveness. Fasting also provides an opportunity for the heart muscle to improve the vitality and strength of its cells.

Other research conducted by Sri Astuti k Zulianti revealed that fasting has benefits for physical health, preventing heart disease, increasing white blood cells, avoiding cancer and diabetes, and reducing smoking addiction. During fasting, the amount of food that enters our body is reduced. The food we eat $90 \%$ cause of diseases. We do not know the number of carbohydrates, sugars, or food flavors in the food, which we know is delicious. Therefore we must be able to sort out any food that is healthy for ourselves. Healthy food must be halal because halal food can affects our body. If the food we eat is halal, it is perfect for our body as we know that the food that enters will be digested by the stomach and produce blood that flows inside us if we eat food that is forbidden and the blood that flows in our body.

In addition to the benefits of fasting in physical terms, there are also benefits from the spiritual aspect. A healthy spirit is supposed to build a healthy body. Some diseases occur only due to physical, but the other cause is a spiritual illness. Fasting can cure spiritual illness. Rasulullah Saw. said, "The heart can rust, and its healing is with the Qur'an." The rusty heart is difficult to accept the teachings of the Qur'an and the teachings of the Prophet. Therefore, these spiritual illnesses can be cured by fasting. For example, stingy people can be healed with generosity.

Ramadan fasting is an obligatory fast that must be performed for Muslims. Ramadan fasting is a fast performed in the month of Ramadan with a total of between 29 and 30 days in fasting. According to the teachings of Islam in fasting in the month 
of Ramadan we can remove mistakes or be forgiven of sins that have been committed so far. There are studies that explain the effects of Ramadan fasting performed by a Muslim on the body's metabolism, among others on weight, glucose metabolism, and lipid metabolism (Firmansyah, 2015)

Apart from fasting in Ramadan, there are also sunnah fasts, which include:

- Sunnah Fasting (Monday-Thursday) . Rasulullah has ordered his people to always fast on Mondays and Thursdays because Monday is the day of his birth, and Thursday is the first day the Qur'an was revealed. On Monday Thursday, human deeds are examined so that he wants when checked, he is in a state of fasting.

- Shawwal Fasting is fasting six days in the month of Shawwal or after the month of Ramadan. It can consecutively start from the second day of Shawwal or not. Rasulullah said which means: "The virtue of Ramadan fasting accompanied by the Shawwal fast is like a person who fasts for a year (HR. Muslim).

- Fasting Muharram is fasting in Muharram's month, and the most important is that on day ten assyuro the sacred month '. This fasting has virtue and is the most important after the fast of Ramadan.

- Arafah fasting is on the 9th day of Dzuhijjah, where the specialty is that the sins of the past year will be washed away \& the sins in the coming year (Narrated by Muslim). The sins referred to are specifically for minor sins because big sins can only be forgiven by "taubatan nasuha"

- Fasting in the month of Sha'ban. All the deeds will be raised to the Rabb ordered to increase their fasts.

- Daud fasting. The Prophet Daud did, and the method, namely one day of fasting and one day not or alternating and fasting, was favored by Allah SWT.

Research shows the wisdom and benefits of fasting on human health, a preventive and curative against several diseases. Allah said, "And if you are fasting, surely it is better for you if you know it." (Surah al-Baqarah: 184). Physical health and mental health are related. That is, if one is disturbed, it will affect the other part. Therefore fasting is selfcontrol so that humans avoid all kinds of dangers, both from diseases and things that are not praiseworthy that are not liked by Allah SWT. It is a blessing given by Allah SWT. Everything that happens and the whole world is already in the Qur'an, starting from the minor thing, has been arranged in the Qur'an, the same is about human life, from the way to dress to talk. Therefore, we as humans must be more able to control ourselves by the teachings that Allah SWT. has given in the Qur'an. 


\section{CONCLUSION}

Fasting is refraining from everything: appetite for food, drink, or sexual activity during the day. Fasting can prevent diseases that arise due to excessive eating patterns. Overeating can cause all kinds of diseases, one of which is diabetes. Besides, fasting helps us calm down anger and maintain the fast sanctity by being patient and holding back anger during fasting. Therefore fasting affects one's self-control.

\section{REFERENCES}

Firmansyah, M. A. (2015). Pengaruh Puasa Ramadhan pada Beberapa Kondisi Kesehatan. Cermin Dunia Kedokteran, 42(7), 510-515.

Gusmian, I. (2015). Epistemologi Tafsir al-Qur'an Kontemporer. Al-A'raf: Jurnal Pemikiran Islam Dan Filsafat, 12(2), 21-32.

Julianto, V., \& Muhopila, P. (2015). HUBUNGAN PUASA DAN TINGKAT REGULASI KEMARAHAN. Psympathic: Jurnal Ilmiah Psikologi, 2(1), 32-40.

Kadir, S. (2019). Pola Makan dan kejadian hipertensi. Jambura Health and Sport Journal, 1(2), 56-60.

Nuraisyah, S. (2019). Pengaruh puasa senin kamis terhadap pengendalian emosi remaja: Studi kasus pada siswa-siswi kelas VII MTs. Multazam Bandung. UIN Sunan Gunung Djati Bandung.

Royanulloh, R., \& Komari, K. (2019). Bulan ramadan dan kebahagiaan seorang muslim. Jurnal Psikologi Islam Dan Budaya, 2(2), 127-138.

Setiawan, A. (2017). UBUNGAN ANTARA PUASA SUNNAH DENGAN SIKAP SOSIAL SISWA (Studi di MTs Negeri Model 1 Pandeglang). Universitas Islam Negeri" Sultan Maulana Hasanuddin" BANTEN. 